\title{
THE IMPLEMENTATION OF INTERNATIONAL ANTI-CORRUPTION LAW IN BUSINESS: LEGAL CONTROL OF CORRUPTION DIRECTED TO TRANSNATIONAL CORPORATIONS
}

\author{
Luciano Vaz Ferreira ${ }^{1}$, Fabio Costa Morosini ${ }^{2}$
}

\section{Introduction}

Corruption is no longer seen as a problem of underdeveloped nations, but a matter of international concern. Based on the international initiatives and exchange of experiences among countries, new strategies for control of corruption have been developed. A new approach, inspired by the "principalclient-agent" model, proposes the development of anti-corruption policies directed to the private sector. The idea is to implement mechanisms that attack the supply side of corruption to reduce its occurrence. The lack of territorial barriers for enterprises and the emergence of transnational corporations in the context of globalization represent a challenge for the implementation of anticorruption mechanisms. This also reinforces the need for establishment of an international policy about this issue.

\footnotetext{
${ }^{1}$ Professor of Law. Juridic assessor of the Secretariat of Justice and Human Rights of the Province of Rio Grande do Sul, Brazil. Doctorate student of International Strategic Studies at Universidade Federal do Rio Grande do Sul; Master in International Economic Law at Universidade do Vale dos Sinos and Graduation in Law at Pontifícia Universidade Católica do Rio Grande do Sul.

${ }^{2}$ Professor of Law at the Faculty of Law of Universidade Federal do Rio Grande do Sul, Brazil. Doctor and Master in Law at Texas University, Austin; Master in Law with honor mention at Université Paris 1, Panthéon-Sorbonne, Institut d'Études Politiques de Paris; graduation in Law at Pontifícia Universidade Católica do Rio Grande do Sul.
} 
This research aims to analyze the evolution of international mechanisms for control of corruption directed to transnational corporations. The focus will be on the initiatives of international organizations (OAS, OECD and UN) in the form of international treaties. The goal is to identify the existence of an international anti-corruption regime, composed of a specific legal framework, which is able to compel States to fight against corruption.

The research is exploratory in nature. It is an introduction on the subject, especially for policymakers from countries with emerging economies, like Brazil, that are not yet familiar with the study of control of corruption. It was decided to conduct a bibliographic review, using interdisciplinary sources.

The article is developed in four sections. The first part deals with the phenomenon of corruption, providing definitions, possible causes and consequences. The second part explores the relationship between the private sector and corrupt practices, focusing on the conduct of transnational corporations. The third part refers to the construction of an international anticorruption regime. It is necessary to seek its origin, found in the U.S. anticorruption law. In this segment are also studied efforts of international organizations in establishing an international policy to control corruption, represented by the creation of international treaties on the subject. In the last part are discussed the consequences of the existence of an international corruption regime and the Brazilian context.

\section{The Phenomenon of Corruption}

The World Bank $(1997,08)$ defines corruption as "the abuse of public office for private gain". The definition is broad and includes a series of behaviors. The most apparent is the practice of bribery, involving civil servants who require or request improper advantage and private agents who pay these values to have some benefit from the government. Patronage and appropriation of public resources are also included in the definition of corruption.

Transparency International $(2008,02)$ understands corruption as "the abuse of entrusted power for private gain". There is no reference to the word "public office". This idea allows the existence of corrupt practices involving only private actors ("private or corporate corruption"). 


\section{Luciano Vaz Ferreira and Fabio Costa Morosini}

Researching the causes of corruption, there is a risk to get stuck in a counterproductive discussion about problems of morality and cultural determinism. In Brazil, there is the idea that corruption is inherent to the Brazilian culture, a kind of "damned inheritance", which can only be overcome by a utopian revolution of values. However, some studies show that corruption is as old as the existence of the State, found in several periods of human history (Tanzi 1998, 559), and universally condemned (Noonan Jr. 1989). There are reported cases in several countries, regardless of economic status (Klitgaard 1994, 22-28; Rose-Ackerman 1997, 32).

A new point of view can be used to approach the problem of corruption, seeking inspiration from economic reasoning. The idea is to understand corruption as a result of constant interaction between public and private interests within the State structure. According to Rose-Ackerman (1997, 31) there are incentives for corrupt practices whenever a public authority exercises his discretion on the distribution of a benefit or a cost to the private sector. It is well known that the State has the power to buy and sell goods and services, offer concessions and distribute subsidies (benefits), as well as collect taxes, enforce regulations and require authorizations (costs). On the other hand, there is a private sector with economic power and ready to pay for benefits or to reduce the costs that were imposed. As all the activities mentioned are inherent to the functioning of a government today, creating incentives for corruption is inevitable.

The "principal-agent-client" model, proposed by Klitgaard (1994, 83), helps to understand the dynamics of corruption. The "principal" can be represented as a superior officer in public administration, the "agent" as a petty officer responsible for maintaining contact with the "client"; the "client" represents the private sector. They all have independent interests.

The "principal" responsible for implementing an anti-corruption policy in his administration should know that the "agent", although inserted in the State structure, makes his own calculations in order to measure the profits of accepting a bribe and the probable costs to be identified and punished. In the same way, the "client" will be compelled to try to corrupt the "agent" in order to obtain benefits or reduce costs, unless he is able to glimpse the possibility of punishment. As may be seen, corruption is a "crime of calculation", a matter of 
opportunity. "People will tend to engage in corruption when the risks are low, the penalties mild, and the rewards great" (Klitgaard et al. 2000, 27).

An extensive survey of literature suggests that corruption causes serious economic and social damage, which justifies the establishment of policies for its control. Below are enrolled the principal negative consequences of corruption:

a) Fiscal controls tainted by corruption facilitate tax evasion, causing losses to the government budget (Mauro 1997, 87).

b) In a corrupt environment, the government can give priority to public works of little benefit to the general population rather than investments in education and health (Shleifer and Vishny 1993, 616).

c) Without strong deterrents to corruption, the competition to take advantage of the benefits offered by the government will be influenced by the conduct of the least scrupulous participants (Heimann 1997, 148). In a bidding process, the one that offers the best quality or price for his service will not win, the chosen will be the one who maintains an unlawful relationship with the government.

d) Research conducted by Wei (2000); and Teixeira and Grande (2011) indicates that the perception of corruption in a country may negatively impact on its ability to attract foreign direct investment, because of the high cost to maintain enterprises in an environment of corruption. This situation is especially troublesome for developing countries, which need foreign capital for technology transfer, acquisition of know-how and realization of large infrastructure projects (Sornarajah 2010, 48).

\section{Corrupt Practices and Transnational Corporations}

Anti-corruption policies are usually concentrated in the role of the "agent", with the monitoring of their conduct and application of severe penalties for the corrupt. Despite the undeniable importance of these mechanisms, in recent years a more comprehensive approach has been more widely adopted. This approach includes the role of the "client" in the development of control for corruption.

Milton Friedman (1970) once said that the "only social responsibility of business is to increase its profits". This assertion reflects the economic rationale that drives the enterprises, but does not correspond to today's societal 


\section{Luciano Vaz Ferreira and Fabio Costa Morosini}

expectations over private sector's behavior. Nowadays, the concept of governance prevails: the problems of society shall not be administered only by the State, but also by international organizations and private actors (such as individuals, nongovernmental organizations and corporations) (Comissão sobre Governança Global 1995, 02). In a governance environment, companies are responsible for the impact that their "activities may have on the social, political, economic and developmental aspects of society" (Adeyeye 2011, 149).

In this context, the responsibility for the control of corrupt practices is not only from the State but shared with the business. It creates the idea that the private sector may be the main responsible for providing fuel for the machinery of corruption (Transparency International 2008, 02).

It is up to the government to create a system of incentives and punishments to make corruption less attractive to corporations. The development of "national anti-corruption law" focused on business practices can be an important mechanism for this purpose.

It is not, however, an easy task. One of the challenges is related to the nature of contemporary business structures. While the mechanisms of State control are limited to the national territory, corporate activities transcend borders in the figure of "multinational" or "transnational corporations", enterprises that organize their activities in more than one country ${ }^{3}$. According to data from 2009-2010, it was estimated that there are 82,000 transnational corporations (TNCs) worldwide, with $\mathbf{8 1 0 , 0 0 0}$ foreign affiliates (UNCTAD 2009, $\mathrm{xxi}$ ). They are responsible for more than a quarter of gross world product and more than a third of exports (UNCTAD 2011, 24). Studies indicate that there are TNCs with gross domestic product larger than many nations (Grauwe and Camerman 2003, 27).

TNCs participation in corruption schemes is very common. This connection has been justified for years as necessary to conduct business in other

${ }^{3}$ TNCs are not limited to import and export operations, they realize long term investments abroad ('foreign direct investment'). According to World Bank, foreign direct investment are 'the net inflows of investment to acquire a lasting management interest (10 percent or more of voting stock) in an enterprise operating in an economy other than that of the investor'. It is divided into "greenfield investment", when the foreign investor opens a new venture, and "cross-border merger and acquisitions", when the investor buys or makes merging with existing enterprise. 
countries, especially the "undeveloped", where there would be a culture of corruption. Until recently, European countries allowed corporate tax deductions for overseas bribes (Naim et al. 1997, 13). This situation benefited the corrupt corporations at the expense of honest companies in gaining access to foreign markets, while they helped in maintaining highly corrupt governments. In the face of this scenario, it is necessary to build an international regime of corruption control with a focus on private sector. The goal is to create a compromise between countries in confronting the problem through the exchange of experiences and the harmonization of national laws, preventing the existence of zones of impunity. The focus on TNCs can make a difference. According to Naim et al. (1997, p. 22-23), it is easier to prevent corruption in TNCs than imposing complex institutional reforms in several developing countries. The attack on the supply side of corruption makes it more difficult to corrupt agents to reach their objectives. Another important aspect is the possibility of these TNCs disseminate their values around the world among its business partners, which will be compelled to adopt anti-corruption practices at the risk they will not be able to do business with ethical companies in the future.

\section{The International Anti-Corruption Regime}

\subsection{The U.S. Foreign Corrupt Practices Act (FCPA)}

The United States was the first country to be concerned about the connection between TNCs and the phenomenon of corruption.

The political context of the country in the $70 \mathrm{~s}$ was decisive. After the Watergate scandal, which President Nixon was accused of using his power to illegally spy on political opponents, a series of investigations was conducted by the U.S. Senate to find irregularities in the government. While investigating the financing of political campaigns, it was discovered the existence of irregular funds maintained by U.S. TNCs for the purpose of bribing foreign governments to ensure lucrative business in these countries. In collaboration with the U.S. Securities and Exchange Commission (SEC), the agency responsible for regulating the stock market in the U.S., more than five hundred U.S. companies 
have admitted paying the equivalent of 300 million dollars in bribes to foreign officials (Biegelman and Biegelman 2010, 10).

Despite the existence of a solid set of norms that prohibit bribery of national public servants in the United States, there was nothing in the U.S. law about the bribery of foreign public officer. Inspired by the "wave of moralizing" it was sanctioned in 1977 by President Jimmy Carter, the Foreign Corrupt Practices Act (FCPA), law that prohibited the payment of bribes to foreign officials in order to establish lucrative business relationships. At the time, the President made the following statement: "bribery is ethically repugnant and competitively unnecessary. Corrupt practices between corporations and public officials overseas undermine the integrity and stability of governments and harm our relations with other countries" (Koehler 2010, 913).

The FCPA is an U.S. law with extraterritorial enforcement, aiming to prevent and punish the use of bribery abroad by corporations. The legislation applies not only to U.S. companies, but also to their subsidiaries operating in foreign countries, joint ventures, and even foreign companies with operations or mere registration in the U.S., as well as companies that trade on the stock exchange $^{4}$.

The law provides preventive and repressive measures. The supervision of the application is made by the SEC and the Department of Justice (DOJ). The subjects of the FCPA are required to keep detailed records of all financial and commercial transactions and carry out internal and external audits periodically. Penalties for those violating the FCPA may be of a civil (such as fines and prohibition from contracting with public administration) or criminal nature (imprisonment for executives and employees).

The government maintains the "whistleblower bounty program", giving rewards for whistleblowers that indicate violations of the FCPA. A curious fact is that the FCPA cases are rarely decided by a U.S. Court: the tendency is to sign agreements with regulators.

The impact of the FCPA in the activities of companies is a matter of disagreement in the U.S. Part of the business community believes that the

\footnotetext{
${ }^{4}$ In 1975, only $2.12 \%$ of companies listed on the New York Stock Exchange (NYSE) were foreigners. In 2005, the percentage was 37\%. All are subject to the FCPA (Tafara and Peterson 2007, 34).
} 
legislation created a competitive disadvantage for U.S. companies compared to companies from countries where such corruption is allowed. Unable to bribe, the companies would soon lose markets, bringing consequences for the U.S. economy (Naim et al. 1997, 17-19). On the other hand, there is the argument that reducing corruption helps maintain an environment of equal conditions for competitiveness abroad ("level playing field") between U.S. companies and their partners. The weight of the U.S. economy and the extraterritorial nature of FCPA fulfill an important role in the dissemination of corporate governance around the world.

\subsection{International Anti-Corruption Treaties}

With the implementation of the FCPA, the U.S. government started to press for the internationalization of the fight against corruption and the adoption by countries of similar law. Thus, it would overcome the discrepancies between the regulatory conditions for U.S. companies and from other countries, which would be bound by the same international anti-corruption regime. In the words of Carr and Outhwaite $(2008,07)$ :

\footnotetext{
"The U.S recognized that bribery of foreign public officials was not simply a U.S problem but a universal one. In aggressively promoting the adoption of similar legislation in other industrialized countries the U.S sought to ensure a level playing field for competing businesses and to increase market integrity and stability".
}

The U.S. strategy was to take the issue for discussion in international forums. In 1975, the General Assembly of the United Nations (UN) condemned the corruption perpetrated by transnational corporations. The following year, it was the turn of the Organization for Economic Cooperation and Development (OECD). France, Germany and the United Kingdom were opponents of the initiative, pointing out that the fight against corruption should be directed solely to the actions of public servants. The FCPA was accused of being an illegal exercise of extraterritoriality, and a treaty on these lines would be the imposition of an international criminal code, infringing State sovereignty (Naim et al. 1997, p. 20). 


\section{Luciano Vaz Ferreira and Fabio Costa Morosini}

In the $90 \mathrm{~s}$, the negotiations for an international anti-corruption agenda continued. In 1993, the Clinton administration placed as a priority in its trade policy the development of an international anti-corruption treaty. The American victory was not caused by its ability to negotiate, but because of the headlines from newspapers. The period was marked by a series of investigations involving misconduct of European (most notably Germany, France and Italy) and Asian politics, so that the defence of any form of corruption would not be forgiven by the international public opinion.

At this point, it was possible to glimpse the establishment of an international treaty. The international institution initially chosen for the implementation of this project was the OECD, which discusses issues involving development, democracy and free markets. It is composed traditionally by developed countries (and some developing) and represents the main competitors of U.S. for business opportunities abroad ${ }^{5}$.

In 1994, the OECD Council has met to issue the following statement: "bribery is a widespread phenomenon in international business transactions, including trade and investment, raising serious moral and political concerns and distorting international competitive condition". The document indicates that the responsibility in confronting corruption in international transactions is shared by all countries. Thus, calls upon Member States to take necessary measures to combat the phenomenon, through reforms of its domestic law.

The discussions about the resolution were responsible for triggering a series of other international initiatives. Regionally, there were the first meetings of the Council of Europe and the Organization of American States (OAS) to address the problem of corruption. Meanwhile, the UN intensified its discussions on the subject.

At the OAS, the "Inter-American Convention against Corruption" was created. It was signed in 1996 and became effective in 1997. Provides that

5 Today, the organization has 34 members: Australia, Austria, Belgium, Canada, Chile, Czech Republic, Denmark, Estonia, Finland, France, Germany, Greece, Hungary, Iceland, Ireland, Israel, Italy, Japan, South Korea, Luxembourg, Mexico, Netherlands, New Zealand, Norway, Poland, Portugal, Slovakia, Slovenia, Spain, Sweden, Switzerland, Turkey, United Kingdom and the United States. Due to the current configuration of the global economy, the organization maintains a strong channel of communication with Russia, China, India, South Africa, Indonesia and Brazil. 
States Parties shall prohibit the offering of bribes to domestic public officials (article VI) and foreign officials (article VIII). Clearly influenced by the FCPA, the regional instrument made history by being the first to deal, albeit briefly, with bribery carried out by transnational corporations.

In the text of the treaty can be highlighted the protection of whistleblowers (article III.8), the establishment of a governmental agency for corruption control (article III.9) and the obligation to maintain detailed accounting records by companies to facilitate detection of corruption (article III.10).

The main flaw of the treaty is the absence of mechanisms to evaluate compliance. Evaluation mechanisms were only implemented in 2003 and still require further development (Webb 2005, 194).

In December of 1997, the "OECD Convention on Combating Bribery of Foreign Public Officials in International Business Transactions" was finally signed. Currently, the participating States are OECD members plus Argentina, Brazil, Bulgaria, South Africa and Russia. The workgroup about bribery is also integrated by China, Peru, Indonesia, Malaysia and Colombia, which may sign the Convention in the future. It entered into force in 1999.

The biggest difference compared to the document OAS Convention is its global reach. Like the FCPA, its source of inspiration, the OECD Convention deals only with bribery involving foreign public officials, a situation related to international business. The strategy is to establish a political and legal commitment between the signatory States to modify national law in order to prohibit corrupt practices harmful to transnational economic relations (article 1.1).

It is observed that the list of signatories is composed of developed and developing countries that account for $90 \%$ of foreign direct investment, $2 / 3$ of the international trade and 75\% of transnational companies (OECD 2011a, 01). The objective of the treaty is the prevention and punishment of corrupt practices by bribe payers, it is understood that the attack on the main financial source of corruption would cause its "starvation". The prohibition of the use of corruption in international business represents an attempt to "level the playing field" of economic forces in a context of global free market, the main United States' goal in the internationalization of corruption control. 
The OECD Convention adopts a style that is also present in other anticorruption treaties: the international instruments are unable to automatically prohibit corrupt conduct, even in the existence of the ratification process. It is necessary that Member States create their own national laws in order to criminalize such conduct and implement its control mechanisms.

Thus, the international legal instrument merely presents "templates" that can be copied by the signatory States, similar to a "soft law". If the legislative procedure is not performed, such clause of the treaty is not applied. While the domestic regulations are not created, other states may press for the signatory countries to take action, through monitoring mechanisms.

The Convention requires that the attribution of the conduct of bribe a foreign public official to be extended to legal persons (article 2). There is also a requirement for maintaining detailed accounting records, auditing systems and the dissemination of companies' financial statements (article 8.1).

According to the treaty, criminal, civil or administrative penalties must be implemented for the wrongdoers. The OECD exemplifies some types of noncriminal penalties: exclusion from access to public resources, the temporary prohibition from participating in bidding, and the prohibition on practicing certain commercial activities (OCDE 2011b, 16).

The mechanism of monitoring and evaluating implementation of the OECD Convention is one of its major highlights, due to its degree of accuracy, detail and rigidity. Currently the process is composed of three phases and conducted by a working group composed of teams of experts from Member States.

The first phase analyzes whether the country has implemented national anti-corruption law in accordance with the parameters of the OECD Convention. For this, the State responds questionnaires and submits its legislation and legal texts for evaluation. In the second phase, the effectiveness of the law is evaluated. To do so, visits to the country are scheduled and meetings are conducted with social actors in various segments such as government, chambers of commerce, development agencies, business and civil society. The reports produced by the experts are extremely detailed. They evaluate the changes made in national legislation, statistics from criminal prosecution, public awareness, details of sanctions and degree of international 
cooperation (Carr and Outhwaite 2008, 08; Webb 2005, 197). The third phase, recently implemented, consists of periodic evaluations carried out in order to observe the evolution of the national anti-corruption mechanisms.

After signing the OECD treaty, the institution began to issue recommendations in order to detail the obligations. It is the use of "soft law" to avoid an exhausting and complicated treaty reform. It has created a complementary framework to the Convention of great importance, since the parameters set out in these recommendations are being used by the OECD in the evaluation of compliance with the treaty.

Member States are recommended to end the tax deductibility of bribes, for too long accepted in industrialized countries. Another document recommends that countries monitor the spread of bribes to foreign officials in export operations, especially those assisted by programs of official credits and government funding agencies. Countries should also maintain accessible channels for submitting complaints to the competent authorities and to protect whistleblowers.

Recommendations also deal with the need to set up a culture of transparency in business, in order to prevent and detect cases of transnational corruption. In addition to the supervision of the accounting records mentioned in the Convention, OECD recommends the establishment of a program of "internal controls, ethics and compliance", based on a "best practices guidelines" and the maintaining a system of independent external audit. Governments may require the maintenance of compliance mechanisms to participate in public procurement (concessions, bidding) or access to funding programs and public credit.

After the OECD initiative, several regional anti-corruption treaties were created $^{6}$. These efforts culminated in the creation of a new treaty with

6 From Europe, "Convention on the Protection of the European Communities' Financial Interests" (1995), "European Union Convention on the fight against corruption involving European officials or officials of Member States of the EU" (1997), "Council of Europe Criminal Convention on Corruption" (1999), and "Council of Europe Civil Convention on Corruption" (1999). From Africa, "SADC Protocol against Corruption" (2001) and "African Union Convention on Preventing and Combating Corruption" (2003). 


\section{Luciano Vaz Ferreira and Fabio Costa Morosini}

global reach. In 2003, it was signed in Merida at the UN Convention against Corruption. It entered into force in 2005.

The main difference of the UN Convention, in relation to the OECD Convention, is the imposition of the prohibition of practice of bribery involving not only the foreign official (article 16) and also the national official (article 15). The treaty is directed to all countries, unlike the OECD, which targets the supply side of the bribery. The UN treaty has been ratified by 159 countries. The international treaty also requires that the conduct of corruption is also attributed to legal persons (article 26). Regarding preventive mechanisms applied to companies, the treaty establishes audits and control systems and audits (article 12.1); maintenance of books and disclosure of commercial financial statements (article 12.3); dissemination of codes of conduct (article $12.2^{\circ} \mathrm{a}^{\prime}$ ); and prevention of conflicts of interest (article $12.2^{\circ} \mathrm{a}$ '). The treaty also states that should be guaranteed protection to whistleblowers (article 33). Evaluation mechanisms were not implemented until 2009, and they still require further development.

Because of the range of the theme (dealing with all types of corruption) and geography (universal), Carr $(2007,26$.) considers the possibility that the countries denounce the treaties and focus all their efforts in the UN initiative. Although it is simpler to centralize the international anti-corruption policies in a single treaty, it should not discard the role of the OECD, which develops an intense work on the detailing and updating of anti-corruption mechanisms through soft law. Also, the OECD treaty provides an evaluation mechanism more developed than the UN. Thanks to the pressures made by this evaluation procedure, several countries have reformed their anti-corruption law. The OECD's official position is that both treaties are complementary $(2011 \mathrm{~b}, 46)$. It is understood that the pluralism of legal sources, inherent to international law, is a positive aspect because it allows the multiplicity of experiences.

\section{The regulatory race to the top and the Brazilian case}

As a result of massive linking to different international legal instruments and the international awareness of the damage that corruption causes in the world economic system, the signatory States promoted national legal reforms in order 
to restrain the practice of corruption in international business. In this step, the international treaties play an important role, because they spread successful experiences from many countries and establish mechanisms for mutual evaluation. It brings dynamism to the legal instrument, because establishes a forum for dialogue between the various national regulators, while compelling States to fulfill the treaty, forcing the adoption of practical measures.

The result was the occurrence of the anti-corruption phenomenon called "regulatory race to the top", which was extremely beneficial for the international community. Today, most major economies have reformed their legislation to prohibit bribery in international business. Among them are the U.S. legislation (FCPA), obviously, and the reforms that occurred in Germany (1998), France (2000 and 2007), Japan (2005) and the United Kingdom (UK Bribery Act 2010). Brazil, Russia, China and India are in the process of adapting their legal framework.

The first cases of application of the international anti-corruption, some involving multiple jurisdictions, have been reported. According to OECD data, since the entry into force of the treaty have been punished more than 290 companies in 13 countries (OECD 2011a, 01-02). Two famous cases demonstrate the strength of the regulatory regime.

In 2008, the U.S. DOJ announced a lawsuit against Siemens, the giant German technology company. The company was subject to the FCPA because they had issued shares on the New York Stock Exchange. Investigations showed that the company had paid the equivalent of 1.4 billion dollars in bribes in several countries. In order not to suffer a more severe punishment, Siemens confessed the irregularities and agreed to pay a large fine to the U.S. and German governments to suspend the practice (Koehler 2010, 991-993). Since then, the company sponsors academic projects aimed at the dissemination of ethical principles in business.

The other known case occurred in 2010, with BAE Systems, from United Kingdom's defense industry. The company was accused by the government (DOJ / SEC) and UK (Serious Fraud Office) for the use of corrupt practices to win contracts for the sale of weapons to foreign governments. Its main partners were Saudi Arabia, Latin America, Africa and Eastern Europe. The case has not yet been resolved (Koehler 2010, 993-996). 
The inclusion of Brazil in the international anti-corruption regime is a challenge, deserving a detailed study. This is a country with a fast economic ascension, being considered as the seventh largest economy and the fifth country to receive more foreign direct investment. On the other hand, the country is perceived to be highly corrupt ${ }^{7}$.

The country ratified the three international treaties on the subject (OAS, UN and OECD) and currently prohibits the practice of corruption in international business under domestic law. However, the implementation of anti-corruption mechanisms has been considered to be ineffective in certain points of OECD evaluations. The main criticisms are the lack of an effective legal framework to punish companies linked to corruption; absence of a program for the protection of whistleblowers; and need for further development of accounting regulations, internal control and external audit in order to detect foreign bribery.

It is unclear if noncompliance of the international anti-corruption regime by an emerging country (such as Brazil) can cause economic loss, or if is it just a matter of international politics. Evidence points to the first option.

First, control of corruption in Brazilian companies that operate in the country helps the country to do business with foreign companies that want to invest in Brazil. The investing companies will likely come from countries with an anti-corruption regime with extraterritorial application. Therefore, the perception that Brazilian partners maintain an illicit relationship with their government can frustrate business. In this context, it has become usual practice for foreign investors to conduct complex audits before mergers, acquisitions or joint ventures with Brazilian enterprises, in order to ensure the absence of corrupt practice and avoid a possible penalty of their home state.

\footnotetext{
${ }^{7}$ In the latest report of Transparency International (Corruption Perceptions Index 2011), Brazil received the grade 3.8. It has the No. 73 position among 182 countries evaluated. This is a 'perception' of corruption: as the world community views the problem in that country. The ranking is developed through interviews conducted by respectable institutions, reflecting the views of observers around the world. They are consulted experts, risk analysts and businessmen, including people who live and work in the countries evaluated.
} 
Two academic studies confirm the argument. Weitzel and Berns (2006, 01 , in an analysis of almost 5,000 mergers and acquisitions involving foreign direct investment, found that environments with high levels of corruption reduce the rating of national companies, making them less attractive to investors. By conducting an empirical study, Cuervo-Cazurra (2008, 02) found that investor countries that have implemented the OECD Convention reduced their foreign direct investment in corrupt States after their home countries passed laws against foreign bribery.

Second, the incentive to create mechanisms for preventive control of corruption (compliance) in Brazilian transnational companies helps to prevent these enterprises from punishment abroad. The regulatory race made the international anti-corruption regime omnipresent. In some jurisdictions, such as the U.S., the mere registration of shares on its stock exchange has characterized the submission of its anti-corruption law. Thus, Brazilian companies that wish to compete in foreign markets must invest in preventing corruption, or will suffer punishment at the place where they intend to do business. The Brazilian government incentives may help in the dissemination of anti-corruption culture among the national companies, preventing major problems in the future.

\section{Conclusion}

From this initial study, some partial conclusions can be made. The existence of corruption is the result of interaction between public and private interests. It is not just a moral issue but a matter of opportunity. A subject will act corruptly when the benefits from corruption outweigh the loss of a possible punishment. The State has to interfere in this process, creating disadvantages for corrupt practices.

The use of the model "principal-agent-client" (Klitgaard) is an interesting proposal for the development of anti-corruption policies. It is imperative to develop strategies designed to control the conduct of the "client", the private sector, which is primarily responsible for fueling the corruption. In this context, cannot be forgotten the role of "transnational corporations". The implementation of anti-corruption mechanisms focused on these companies may be the best way to establish an international control of corruption, given the 


\section{Luciano Vaz Ferreira and Fabio Costa Morosini}

importance that these entities have in the contemporary economy and the range of their activities in the world scenario.

It is understood that the construction of an international anticorruption framework is required because it formalizes a compromise between countries in confronting the problem. The exchange of experiences and harmonization of national law prevent the formation of zones of impunity. The Foreign Corrupt Practices Act (FCPA) emerged in a very particular situation of American politics, but its importance in developing of new global strategies for control of corruption must be recognized. International anti-corruption treaties are clearly inspired by the American experience, which would justify further study of the FCPA.

The existence of an "international anti-corruption regime", composed of a specific legal framework, was recognized. It is observed that these international treaties do not have the power to automatically implement anticorruption mechanisms, requiring legislative reforms in the States Parties. In order to compel States to take action, international organizations maintain evaluation systems that verify compliance with the treaties. As a result, there is a "regulatory race to the top" of anti-corruption standards, beneficial to the entire international community.

With the omnipresence of corruption control in the world, a good option for emerging countries like Brazil is implementing anticorruption measures provided in international norms. Besides the obvious economic and social benefits that the decrease in corruption causes, such as increased efficiency in public spending and "level playing field" for competitiveness, adherence to the legal framework is necessary also to avoid penalties imposed by an international community committed to anti-corruption policy. Control of corruption in Brazilian companies (or companies of other emerging countries) can help to do business with foreign companies that want to invest in the country. It is also important to mention that the implementation of anti-corruption mechanisms is necessary to protect Brazilian transnational companies that operate abroad from possible punishment in the locations where they develop their enterprise. 


\section{REFERENCES}

Adeyeye. A. 2011. "The Role of Global Governance in CSR." Santa Clara Journal of International Law 9 (1): 147-168.

Biegelman, Martin T., and Daniel R. Biegelman. 2010. Foreign Corrupt Practices Act Compliance Guidebook: Protecting your Organization from Bribery and Corruption. New Jersey: John Wiley \& Son.

Carr, Indira. 2007. "Fighting Corruption Through Regional and International Conventions: A Satisfactory Solution?" European Journal of Crime, Criminal Law and Criminal Justice 15(2).

Carr, Indira, and Opi Outhwaite. 2008. "The OECD Anti-Bribery Convention: Ten Years On." Manchester Journal of International Economic Law 5(1): 03-35.

Comissão sobre Governança Global. 1996. Nossa Comunidade Global. Rio de Janeiro: Fundação Getúlio Vargas.

Cuervo-Cazurra, Alvaro. 2008. "The Effectiveness of Laws against Bribery Abroad". Available at: http://ssrn.com/abstract $=1059001$.

Friedman, Milton. 1970. "The Social Responsibility of Business is to Increase its Profits". New York Times Magazine 13.

Grauwe, Paul de, and Filip Camerman. 2003. "Are Multinationals Bigger than Nations?" World Economics 4(2): 23-37.

Heimann, Fritz F. 1997. "Combating international corruption: the role of the business community." In: Corruption and the Global Economy, edited by Kimberly Ann Elliott, 147-161. Washington: Institute of International Economics.

Klitgaard, Robert. 1994. Corrupção sob Controle. Rio de Janeiro: Jorge Zahar Editor.

Klitgaard, Robert, Ronald MacLean-Abaroa, and H. Lindsey Parris. 2000. Corrupt Cities: A Practical Guide to Cure and Prevention. Washington: World Bank Publications.

Koehler, Mike. 2010. "The Façade of FCPA Enforcement." Georgetown Journal of International Law 41(4): 907-1009.

Mauro, Paolo. 1997. "The Political Economy of Corruption." In: Corruption and the Global Economy, edited by Kimberly Ann Elliott, 83-107. Washington: Institute of International Economics.

Naim, Moises, Patrick Glynn, and Stephen J. Kobrin 1997. "The Globalization of Corruption." In: Corruption and the Global Economy, edited by Kimberly Ann Elliott, 07-27. Washington: Institute of International Economics.

Noonan, John T. 1989. Subornos. Rio de Janeiro: Bertrand Brasil.

Organisation for Economic Co-Operation and Development. 2011a. Foreign Bribery Factsheet. Available at: http://www.oecd.org/bribery . 2011b. Commentaries on the Convention on Combating Bribery of Foreign Public Officials in International Business Transactions. Paris: OECD. 


\section{Luciano Vaz Ferreira and Fabio Costa Morosini}

Rose-Ackerman, Susan. 1997. "The Political Economy of Corruption." In: Corruption and the Global Economy, edited by Kimberly Ann Eliott, 31-60. Washington: Institute of International Economics.

Shleifer, Andrei, and Robert W. Vishny. 1993. "Corruption." The Quarterly Journal of Economics 108 (3): 599-617.

Sornarajah, M. 2010. The International Law of Foreign Investment. Cambridge: Cambridge University Press.

Tafara, Ethiopis, and Robert J. Peterson. 2007. "A Blueprint for Cross-Border Access to U.S. Investor: a New International Framework." Harvard International Law Journal 48 (1): 31-68.

Tanzi, Vito. 1998. "Corruption Around the World: Causes, Consequences, Scope and Cures." IMF Staff Papers 45 (4): 559-594.

Teixeira, Aurora A.C., and Marlene Grande. 2011. "Linking Entry Mode Choices of MNCs with Countries' Corruption. A Review." Working Papers 08 - Observatório de Economia e Gestão da Fraude. Available at: http://www.gestaodefraude.eu/images/gf_upload/wp008.pdf

Transparency International. 2008. Bribe Payers Index 2008. Berlin: Transparency International.

. 2011. Corruption Perceptions Index 2011. Berlin: Transparency International.

Wei, Shang-Jin. 2000. "Negative alchemy? Corruption and Composition of Capital Flows." OECD Development Centre Working Paper 165. Available at: URL: http://www.oecd.org/dataoecd/49/16/2072209.pdf

Weitzel, Utz, and Berns, Sjors. 2006. "Cross-border Takeovers, Corruption and Related Aspects of Governance." Tjalling C. Koopmans Research Institute Discussion Paper. Available at: http://SSRN: http://ssrn.com/abstract $=909546$

United Nations Conference on Trade and Development. World Investment Report 2009. Available at: http://unctad.org/en/docs/wir2009_en.pdf

. World Investment Report 2011. Available at: www.unctad-docs.org/UNCTADWIR2011-Full-en.pdf

Webb, Philippa. 2005. "The United Nations Convention Against Corruption: Global Achievement or Missed Opportunity?" Journal of International Economic Law 8(1): 191-209.

World Bank. 1997. Helping Countries Combat Corruption: The Role of World Bank. Washington: World Bank. 


\begin{abstract}
Lately, corruption has become a matter of international concern. A new approach proposes the development of anti-corruption policies directed to the private sector, especially transnational corporations. The idea is to implement mechanisms that attack the supply side of corruption. This research aims to analyze the evolution of international mechanisms for control of corruption directed to transnational corporations. The focus will be on the international treaties. The goal is to identify the existence of an international anti-corruption regime. This research is exploratory in nature. It is an introduction to the subject, especially for policymakers from countries with emerging economies that are not yet familiar with the study on the subject. It was decided to conduct a bibliographic review, using interdisciplinary sources. Some preliminary conclusions were reached. States must intervene in this process by creating disincentives for the realization of corrupt practices by the business sector, especially in relation to transnational corporations. International treaties do not have the power to automatically implement anti-corruption mechanisms, requiring legislative reforms on the part of the States Parties. In this context, the evaluation systems play an important role in compelling nations to take action. As a result, there is a "regulatory race to the top" of anti-corruption norms, extremely beneficial for the international community. With the omnipresence of the corruption control in the world, a good alternative for emerging economies, like Brazil, is implementing anti-corruption measures provided by in international law; otherwise they may suffer losses in their business activities.
\end{abstract}

\title{
KEYWORDS
}

Corruption; Transnational Corporations; International Relations; International Law. 